\title{
RELEVANSI PENGEMBANGAN KURIKULUM MANAJEMEN PENDIDIKAN TERHADAP DUNIA KERJA
}

\author{
Rugaiyah
}

\begin{abstract}
The aims of the research were to know (a) the stackholders' perception on the Education Management Departement, (b) the difference of personal performance between those with and without management education background, (c) the relevance of management education curriculum to the need of working field, and (d) the stakeholder's expectation of the graduates and the academic product. The research was focused on the society's expectation of Management Education Departement that provides the competence of palanning, actating, supervising, and controlling. Applying survey method, the research identified all education managers at central, province, district, subdistrict, and school levels. Samples were chosen using proportional stratified random sampling. The data were analysed quantitatively and qualitatively to draw conclusions indicating that the society needs the graduates of Education Management Department and the existing curriculum is still releveant. The research suggested to improve the quality of instructional process benefitting advanced information and communication technology to meet the developing needs of the society. .
\end{abstract}

Key words: education management, stakeholder, curriculum development,

\section{PENDAHULUAN}

\section{Latar Belakang}

Memahami kebutuhan lapangan merupakan prasyarat utama bagi setiap lembaga yang menghasilkan produk jasa layanan ataupun barang. Jurusan Manajemen Pendidikan (MP) merupakan lembaga pendidikan yang menghasilkan lulusan yang dipersiapkan untuk mengurus bidang layanan jasa pendidikan khususnya pengelolaan pendidikan.

Selaras dengan tuntutan masyarakat yang tinggi terhadap layanan pendidikan, maka selayaknya jurusan MP mampu menghasilkan para lulusan yang kompeten, terampil, dan memiliki kepribadian yang baik, serta bermoral. Untuk menghasilkan lulusan tersebut harus dijalani melalui proses atau transformasi dalam wujud pemberian pengalaman belajar kepada mahasiswa, baik yang berlangsung di ruang kuliah ataupun di luar kampus. Program pemberian pengalaman disusun dalam suatu susunan yang sistematis dan terencana yang disebut dengan kurikulum.

Pada saat ini, jurusan MP sedang menjalankan kurikulum yang cenderung berorientasi kepada substansi kajian teoritik, seperti mata kuliah manajemen sarana pendidikan, manajemen tenaga kependidikan, sistem informasi dan manajemen, manajemen perkantoran, dan mata kuliah lainnya. Selain itu, metode pembelajaran yang digunakan dosen kurang variatif, sebatas pada menggunakan metode ceramah, diskusi, dan penugasan di mana kadangkala dosen tidak memberikan tanggapan atau arahan terhadap hasil karya mahasiswa. Akhirnya, hasil akhir dari perkuliahan tersebut adalah mahasiswa yang sangat pandai dari satu aspek kemampuan saja, yaitu aspek kogitif. Kondisi ini menimbulkan beberapa pertanyaan yang berkaitan dengan kompetensi lulusan dan hasil apa yang mereka dapat: Apakah lulusan jurusan MP mampu melakukan unjuk kerja dan bersaing di pasar kerja? Apakah masyarakat mengenal lulusan jurusan MP dan kompetensi apa saja yang mereka miliki? Jawaban tersebut diasumsikan bahwa sebagian besar masyarakat belum mengenal lulusan jurusan MP bahkan lulusan MP jarang mendapat formasi untuk menjadi Pegawai Negeri Sipil (PNS) pada jajaran di departemen, pemerintah daerah, dan lembaga lainnya.

Secara de facto, pengelolaan pendidikan pada institusi sekolah, kantor pendidikan dari tingkat pusat sampai tingkat kecamatan, lembaga pendidikan dan latihan, melakukan kegiatan perencanaan, pengelolaan, evaluasi, dan pengawasan untuk seluruh aspek manajemen pendidikan, yaitu pada aspek kurikulum, ketenagaan, sarana dan prasarana, peserta didik, keuangan, dan lainnya. Hal ini merupakan aspek kajian yang ada di jurusan MP. Kondisi ini juga memunculkan pertanyaan, apakah para pelaksana pengelolaan pendidikan pada institusi tersebut dilakukan oleh para lulusan MP atau orang-orang yang memiliki kompetensi manajemen pendidikan? 
Jawaban pertanyaan tersebut menjadi pekerjaan besar untuk warga jurusan MP, baik bagi pimpinan, pengelola, para dosen, juga para mahasiswa. Langkah awal yang dapat dilakukan adalah need assessment kompetensi MP dalam rangka penyusunan kurikulum.

Need assessment ini dilakukan untuk mengetahui sejauh manakah stakeholder mengenal dan memahami jurusan MP serta bagaimanakah sikap mereka terhadap jurusan MP. Selain itu juga untuk memetakan sebaran lulusan atau alumni MP yang menduduki jabatan, khususnya yang menjabat di jabatan pengelola pendidikan. Studi ini juga ingin menyibak sejauh manakah tingkat kerelevansian kurikulum MP dengan kebutuhan pasar kerja dan mengetahui pula kompetensi apa yang diharapkan oleh para stakeholder terhadap para lulusan jurusan MP. Berdasarkan uraian tersebut di atas, maka permasalahan dapat dirumuskan sebagai berikut: (1) Bagaimana persepsi stakeholder tentang jurusan MP? (2) Bagaimanakah perbedaan kinerja personal yang berlatar belakang lulusan MP dan bukan MP? (3) Bagaimanakah relevansi kurikulum MP dengan kebutuhan kerja di lapangan? (4) Bagaimanakah harapan stakeholder tentang lulusan MP dan produk akademik MP?

Adapun ruang lingkup kegiatan need assessment ini, meliputi persepsi tentang pemahaman, penilaian, dan sikap stakeholder terhadap keberadaan jurusan MP. Pendapat stakeholder tentang kinerja lulusan MP yang meliputi sikap kerja, kemampuan dalam bekerja, inisiatif, kreativitas, kemampuan menggerakkan, menyusun program/kegiatan, mengelola kegiatan, dan menyusun laporan. Pendapat stakeholder tentang kinerja personal yang bukan lulusan MP, meliputi sikap kerja, kemampuan dalam bekerja, inisiatif, kreativitas, kemampuan menggerakkan, menyusun program/kegiatan, mengelola kegiatan, dan menyusun laporan.

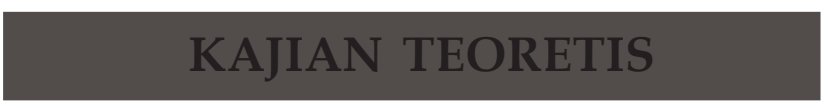

\section{Lulusan Berkualitas.}

Lembaga pendidikan yang sukses adalah lembaga yang dapat menghasilkan lulusan yang berkualitas. Indikator yang berkualitas ditetapkan melalui standar kelulusan yang pada dasarnya merupakan sejumlah kompetensi yang harus dimiliki oleh para lulusan. Kompetensi merupakan sebagai pengetahuan, keterampilan, dan kemampuan yang dikuasai oleh seseorang yang telah menjadi bagian dari dirinya, sehingga dapat melakukan perilakuperilaku kognitif, afektif, dan psikomotorik dengan sebaik-baiknya (Mulyasa, 2003:38). Pendapat lain menjelaskan pula kompetensi adalah penguasaan terhadap suatu tugas, keterampilan, sikap, dan apresiasi yang diperlukan untuk menunjang keberhasilan (Mulyasa, 2003:38). Kompetensi yang harus dikuasai peserta didik perlu dinyatakan sedemikian rupa agar dapat dinilai sebagai wujud hasil pengalaman peserta didik yang mengacu kepada pengalaman langsung lulusan. Hal tersebut sebagai wujud hasil dari proses pendidikan dengan standar kelulusan yang telah ditetapkan diharapkan mencapai titik kualitas yang optimal, di mana kualitas tidak dapat berwujud tetap, tetapi selalu berubah atau dinamis.

Kualitas dapat diartikan sebagai kesesuaian dengan kebutuhan (Hrandesky, 1995:2). Kualitas adalah pemenuhan kebutuhan sejak awal dan setiap saat (Tjiptono, 2000:2). Kualitas adalah kecocokan penggunaan produk untuk memenuhi kebutuhan dan kepuasan pelanggan (Nasution, 2001:5). Dengan demikian, kualitas ditetapkan oleh para pelanggannya. Dalam pendidikan siapa yang dimaksud dengan pelanggan? Apakah lulusan juga termasuk sebagai pelanggan pendidikan? Memahami tentang pelanggan atau stakeholder dalam konteks pendidikan dapat dikutip dari Sallis yang menyatakan bahwa pelanggan pendidikan terdiri dari pelanggan primer sekunder dan tertier - serta pelanggan internal (Sallis, 1993: 32).

Lulusan, dalam hal ini pelajar, adalah pelanggan primer. Pelanggan sekunder adalah orang tua, gubernur atau sponsor; pelanggan tertier adalah pemerintah dan masyarakat pemakai lulusan; dan pelanggan internal adalah guru dan staf pendukung. Lulusan yang berkualitas adalah lulusan yang memiliki kompetensi yang berupa sejumlah pengetahuan, keterampilan, dan sikap sosial yang memenuhi harapan dan kebutuhan pelanggan pendidikan.

\section{Kebutuhan dan Pelanggan/Stakeholder}

Mengkaji tentang kebutuhan dan harapan pelanggan pendidikan pada dasarnya membahas tentang kepuasan pelanggan. Pelanggan atau stakeholder adalah unsur utama yang berkepentingan dalam pendidikan, terdiri dari lulusan (pelajar), orang tua, pemerintah, dan masyarakat.

Diawali dengan memahami kata kebutuhan/ needs yang merupakan sesuatu yang dibutuhkan, hal ini bermakna sebagai pemenuhan sesuatu yang di butuhkan oleh individu atau masyarakat yang dikaitkan dengan kepuasan pelanggan (customer satisfaction). Kepuasan dapat dicapai jika kebutuhan dipenuhi sesuai keinginan dan harapan.

Kepuasan pelanggan adalah respon pelanggan 
terhadap evaluasi ketidaksesuaian yang dirasakan antara harapan sebelumnya dan kinerja aktual produk yang dirasakan setelah memakainya (Tjiptono, 2000:102). Kepuasan adalah respon pelanggan secara langsung dalam menilai sebuah produk atau layanan jasa yang diberikan dengan menyenangkan atau tidak, kepuasan pelanggan adalah tanggapan emosional pada evaluasi terhadap pengalaman konsumsi suatu produk atau jasa. (Hom, 2002).

Kepuasan pelanggan diartikan pula sebagai realisasi respon, hal tersebut merupakan penilaian terhadap produk atau karakteristik layanan pada tingkat yang sangat menyenangkan atau sangat tidak menyenangkan. Kepuasan pelanggan adalah pelanggan yang merasa puas dengan layanan dan menerima kebutuhan-kebutuhannya, keinginan, dan harapanharapan (Stamatis, 1977: 159). Kepuasan pelanggan dijamin oleh produksi kualitas hasil atau layanan yang tinggi (Goetch \& Davis, 1997: 157). Kepuasan pelanggan adalah suatu keadaan di mana kebutuhan, keinginan, dan harapan pelanggan dapat dipenuhi melalui produk yang dikonsumsi (Nasution, 2001:45). Kepuasan pelanggan (customer satisfaction) merupakan perpaduan antara harapan (keinginan dan kebutuhan) pelanggan, manajemen sumber daya manusia, dan operasionalisasi lembaga (Roes, 1995: 207).

Memenuhi kepuasan pelanggan pendidikan dapat dilakukan melalui pemenuhan keinginan/ kebutuhan para pelanggannya. Memenuhi kebutuhan peserta didik (para lulusan) dengan memberikan program (kurikulum) dalam wujud kompetensikompetensi yang dapat dimanfaatkan dalam kepentingan hidupnya baik untuk kepentingan internal dirinya maupun untuk kepentingan pemanfaatan ilmu di masyarakat yang dapat menyokong keberlangsungan hidupnya. Bagi pelanggan sekunder dan tertier, kebutuhan mereka terpenuhi sejalan dengan pemenuhan kebutuhan pelanggan primer atau siswa (baca : lulusan). Sedangkan bagi pelanggan internal, kebutuhannya dipenuhi melalui layanan operasionalisasi lembaga dalam aspek pengembangan profesi dan kesejah-teraan.

Sejalan dengan kebutuhan para pelanggan pendidikan dengan bergulirnya perkembangan global dan kebijakan lokal dibutuhkan suatu pengembangan kurikulum yang memuat program sesuai dengan tuntutan yang berkembang saat ini. Kurikulum yang dibutuhkan oleh masyarakat adalah kurikulum yang sesuai disusun berdasarkan landasan dan prinsip-prinsip yang relevan dengan standar kompetensi yang dibutuhkan saat ini.

\section{Pengembangan Kurikulum}

Secara etimologis, kurikulum berasal dari kata currere; curriculum; a running course; courier: berlari; courses: mata pelajaran (Wasty, 1996:3). Franklin Bobbit yang dikutip Somantrie menjelaskan kurikulum adalah susunan pengalaman belajar terarah yang digunakan oleh sekolah untuk membentangkan kemampuan individual anak didik (Suriasumantri, 2000:2). Kurikulum adalah seperangkat rencana dan pengaturan mengenai tujuan, isi dan bahan pelajaran, serta cara yang digunakan sebagai pedoman penyelenggaraan kegiatan pembelajaran untuk mencapai tujuan pendidikan tertentu.

Beberapa prinsip yang harus diperhatikan dalam pengembangan kurikulum, yaitu prinsip relevansi, fleksibilitas, kontinuitas, efisiensi, dan efektifitas (Suriasumantri, 2000:8). Kurikulum dikembangkan relevan dengan kebutuhan masyarakat, tuntutan pekerjaan, kemajuan teknologi, serta kebijakan yang ditetapkan. Pengembangan kurikulum, fleksibel dengan pengembangan dan pemilihan program yang ditawarkan, selanjutnya kurikulum dikembangkan bersinambung antartingkat dan antarkajian. Pada akhirnya, kurikulum haruslah dikembangkan seefisien mungkin mengingat waktu belajar dan pencapaian sasaran sesuai dengan yang dibutuhkan dan diinginkan.

Pengembangan kurikulum di perguruan tinggi mengacu kepada pengembangan kurikulum berdiferensiasi. Semiawan (1992) menjelaskan kurikulum berdiferensiasi adalah kurikulum yang digunakan untuk anak berkemampuan unggul. Implementasi kurikulum tersebut dijabarkan dari umum serta dilandaskan oleh psikologi perkembangan dan psikologi belajar yang berelevan maupun mencakup uraian mengenai cara-cara teknis pengembangan kurikulum tersebut.

Pengembangan kurikulum ini bertitik tolak dari asumsi bahwa setiap manusia berbeda kecepatan perkembangannya dan bahwa pengabaian dari pemenuhan kebutuhan sesuai sifat dan irama perkembangan tersebut sangat mengganggu perkembangan kurikulum.

1. Kebijakan pengembangan kurikulum dan institusi perguruan tinggi di era kehidupan mendunia.

Dalam era keterbukaan ini, penyelenggara pendidikan tinggi akan menghadapi permasalahan yang secara umum sama, yaitu keadaan penuh ketidakpastian (terraincognita) yang menyebabkan kehidupan menjadi spekulatif, kehidupan yang bersifat paradoksal yang menyebabkan jaminan berkelanjutan kecil, networking yang didasarkan pada mutual benefit dan bukan mutual respect yang menyebabkan munculnya 
hegemoni penyelenggaraan pendidikan, dan adanya dissilusion terhadap pendidikan tinggi yang menyebabkan pendidikan tinggi tidak mampu memberikan jaminan kompetensi lulusan kepada pemakai jasa pendidikan tinggi.

Networking yang dilakukan atas dasar mutual benefit dan bukan mutual respect menyebabkan hegemoni penyelenggaraan pendidikan tinggi. Akhir-akhir ini, banyak perguruan tinggi saling mengadakan kerja sama, tetapi hanya atas dasar mutual benefit dan bukan mutual respect. Artinya masing-masing perguruan tinggi harus mendapatkan keuntungan dari kerjasama tersebut. Penyelenggara perguruan tinggi hendaknya tidak menerima tawaran kerjasama apabila tidak memiliki kapasitas dan potensi untuk bekerja sama.

2. Kompetensi berkarya disusun oleh perguruan tinggi bersama-sama dengan asosiasi profesi dan masyarakat pengguna lulusan hasil pendidikan.

Masyarakat melalui asosiasi-asosiasi akan menentukan jenis-jenis pekerjaan yang memerlukan sertifikasi dan lisensi. Dirjen Dikti melihat kebutuhan masyarakat terhadap pendidikan yang berorientasi kepada kompetensi lulusan dan mengacu kepada Kepmendiknas No. 045/U/2002 tentang kurikulum inti pendidikan tinggi. Berdasarkan kepmendiknas tersebut, penyusunan kurikulum pendidikan tinggi diserahkan pada perguruan tinggi dan program studi untuk dijadikan kurikulum program studi yang bersangkutan.

5. Desain kurikulum adalah sebuah alternatif menuju tuntunan masa depan

Dalam rangka penyesuaian dengan tuntutan baru serta pentingnya orientasi kemasyarakatan tersebut pada gilirannya diperlukan pola adopsi ke dalam pembelajaran yang diawali dengan desain kurikulum atau bahkan perubahan sistem dan paradigmanya, sehingga perubahan tersebut bersifat esensial. Keputusan Mendiknas No. 232/U/2000 tentang pedoman penyusunan kurikulum pendidikan tinggi dan penilaian hasil belajar mahasiswa yang menunjukkan bahwa arah pendidikan lebih humanis sehingga kurikulum perguruan tinggi harus bercirikan.

a. Mencirikan kekhasan peranannya dalam menjaga keserasian antara program yang diselenggarakan dengan aspirasi masyarakat.

b. Mengakomodasikan politisasi pendidikan yang menyatu dengan strategi pembangunan.

c. Kebutuhan pembelajaran sepanjang umur.

d. Arah perubahan prospektif

Kurikulum pendidikan tinggi ini menganut paradigma competence-based approach, yakni kurikulum dikembangkan berdasarkan target kompetensi lulusan yang telah lebih dahulu diformulasikan. Di samping itu, kurikulum pendidikan juga dikembangkan menurut filosofi pendidikan seperti yang telah direkomendasikan oleh UNESCO, yakni learning to know, learning to do, learning to be, dan learning to life together.

Dengan demikian, kurikulum jurusan yang harus dikembangkan sesuai dengan kebutuhan para pelanggannya dan sesuai dengan kebijakan yang berlaku.

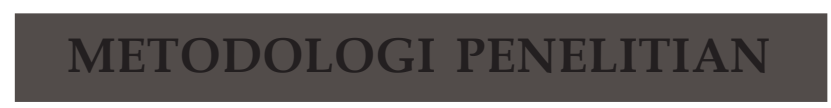

\section{Fokus Kajian}

Kajian penelitian ini difokuskan kepada kebutuhan masyarakat akan jurusan Manajamen Pendidikan yang memberikan kompetensi pengelolaan pendidikan yang meliputi kemampuan merencanakan, melaksanakan, supervisi, dan pengawasan.

\section{Metode Penelitian}

Penelitian ini menggunakan metode survey deskriptif dengan teknik paper pencil dan wawancara. Populasi dan sampel

Populasi penelitian ini adalah para pengelola pendidikan yang tersebar di seluruh unit struktur pendidikan, baik di tingkat pusat, propinsi, wilayah, kecamatan, dan sekolah. Adapun sampel penelitian ditetapkan secara proportional stratified random sampling (sampling acak bertingkat), sedangkan responden, terdiri dari.

a) Para pejabat eselon II, III dan IV di dinas pendidikan dan departemen.

b) Kepala lembaga pendidikan serta latihan pemerintah dan swasta.

c) Kepala TK/PAUD, SD, SMP, dan SMA.

d) Alumni yang bekerja di lingkungan pendidikan.

\section{Model Analisis}

Model analisis data yang digunakan yaitu analisis deskriptif kuantitatif dengan mentabulasi skor. Analisis data dilakukan dengan perhitunan statistika sederhana ataupun statistika inferensial dan analisis kualitatif yaitu dengan menggali informasi secara mendalam, tajam, dan kritis.

\section{HASIL PENELITIAN \\ Deskripsi Data Studi Need Assessment Jurusan Manajemen Pendidikan.}

1. Pendapat tentang Jurusan Manajemen Pendidikan Berdasarkan Data yang Dikumpulkan

Berdasarkan data yang telah dikumpulkan, maka diperoleh gambaran tentang Jurusan Manajemen Perspektif Ilmu Pendidikan - Vol. 19 Th. X April 2009 
Pendidikan, sebagai berikut.

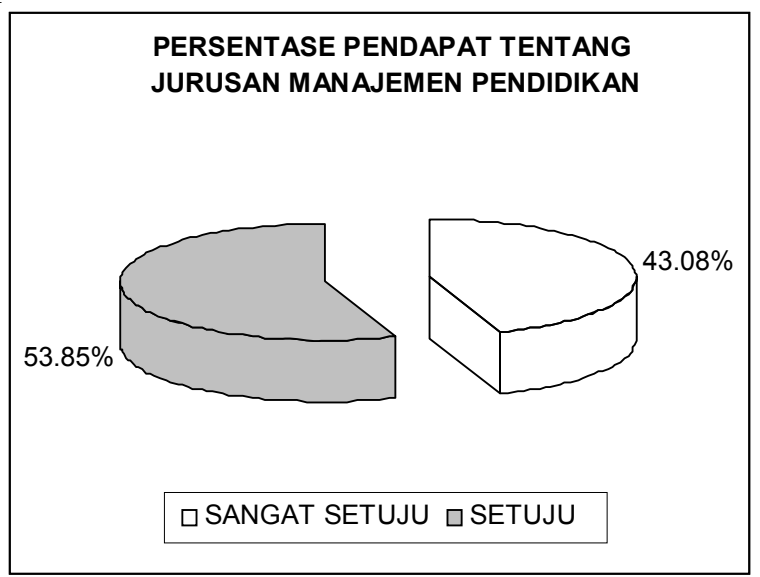

Gambar 1. Persentase pendapat tentang jurusan MP

Berdasarkan gambar di atas, maka diperoleh bahwa $43.08 \%$ menyatakan sangat setuju dan $53.85 \%$ menyatakan setuju terhadap Jurusan Manajemen Pendidikan sebagai lembaga yang menyiapkan sumber daya manusia (SDM) pendidikan yang profesional, SDM yang memiliki kemampuan dan keterampilan teknis di bidang Manajemen Pendidikan, jurusan yang menyiapkan pemimpin yang berorientasi masa depan (visioner), jurusan yang menyiapkan SDM yang memiliki kemampuan di bidang perencanaan, pengelolaan dan pengawasan, serta menghasilkan lulusan yang memiliki kinerja yang memadai.

Pendapat para pimpinan tentang kinerja lulusan (alumni) Manajemen Pendidikan: 38.46\% menyatakan sangat baik, $46.15 \%$ menyatakan baik dan $7.69 \%$ menyatakan kurang baik. Kinerja, dalam hal kedisiplinan, tanggung jawab, loyalitas, dan komitmen. Untuk inisiatif kerja, para lulusan Manajemen Pendidikan, 23.08\% menyatakan sangat baik, 61.54\% menyatakan baik, $7.69 \%$ menyatakan kurang baik. Untuk kreativitas kerja, $30.77 \%$ menyatakan sangat baik, $53.85 \%$ menyatakan baik dan $7.69 \%$ menyatakan kurang baik. Untuk kemampuan bekerja sama, 30.77\% menyatakan sangat baik, $46.15 \%$ menyatakan baik, $15.38 \%$ menyatakan cukup baik. Untuk kemampuan dalam menyusun program, $15.38 \%$ menyatakan sangat baik, $53.85 \%$ menyatakan baik, $15.38 \%$ menyatakan cukup baik dan $7.69 \%$ menyatakan kurang baik. Untuk kemampuan mengelola kegiatan, $7.69 \%$ menyatakan sangat baik, $53.85 \%$ menyatakan baik, $23.08 \%$ menyatakan cukup baik dan $7.69 \%$ menyatakan kurang baik. Untuk keakuratan menyusun laporan, $23.08 \%$ menyatakan sangat baik, $46.15 \%$ menyatakan baik, $15.38 \%$ menyatakan cukup baik dan
7.69\% menyatakan kurang baik. Data tersebut di atas dapat divisualisasikan dalam grafik sebagai berikut :

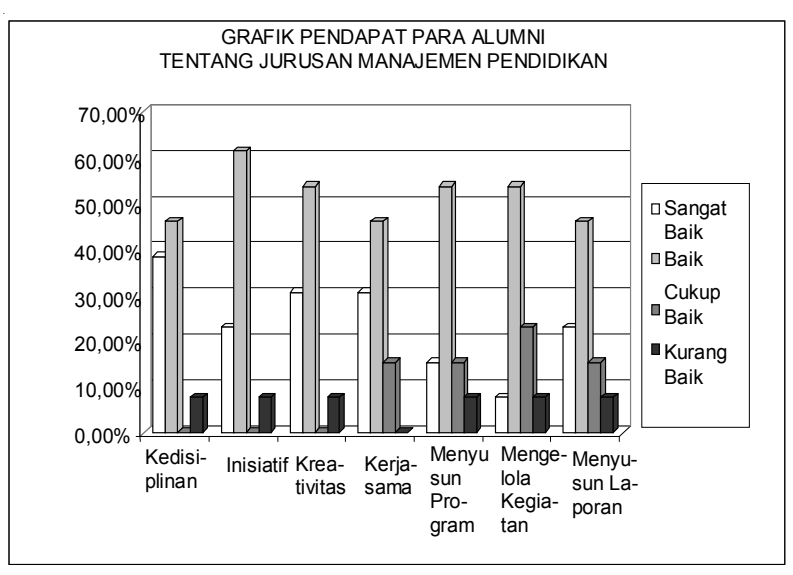

Gambar 2. Grafik pendapat para pimpinan tentang kinerja lulusan jurusan MP

Adapun kemampuan lain yang ditujukan oleh lulusan MP dalam melaksanakan tugas sehari-hari adalah memiliki kemampuan bernegosiasi, memobilisasi, memotivasi, selain itu tanggap, kreatif, disiplin, aktif, terampil, dan inovatif.

Selanjutnya, menurut pandangan para pimpinan tentang kualifikasi yang harus dimiliki oleh para lulusan Manajemen Pendidikan sebagai pengelola pendidikan dan satuan lembaga lain pada multilevel harus memiliki kemampuan merencanakan, mengelola, mengendalikan kegiatan pendidikan, memiliki kemampuan Hi-tech, mampu berkompetisi, dan memiliki jiwa kepemimpinan.

2. Pendapat Alumni tentang Kontribusi dan manfaat kuliah terhadap jabatan dan pekerjaan.

Hasil jawaban dari para alumni secara umum menyatakan bahwa perkuliahan yang diperoleh dari jurusan Manajemen Pendidikan memiliki kontribusi dan manfaat yang sangat besar dan memiliki relevansi yang tinggi dalam melaksanakan tugas sehari-hari.

Gambaran mengenai kontribusi dari masingmasing mata kuliah yang diperoleh, diklasifikasikan menjadi 5 (lima) sub mata kuliah besar, yaitu sub mata kuliah Perencanaan (Perencanaan Pendidikan 1 dan Perencanaan Pendidikan 2), Pengelolaan Manajemen (Manajemen Kurikulum Manajemen Sarana, Manajemen Ketenagaan, Manajemen Keuangan, Manajemen Humas, Manajemen Kesiswaan/Peserta Didik, Manajemen Pendidikan Nasional, Manajemen Sistem Informasi, Manajemen Perkantoran, Manajemen Proyek, Manajemen Mutu Terpadu dan Pengenalan Komputer), Pengawasan dan Kepemimpinan (Supervisi Pendidikan, Pengawasan, dan Kepemimpinan Pendidikan), Keorganisasian (Teori Organisasi, 
Komunikasi Organisasi, dan Perundang-undangan), dan Tugas Akhir (Magang Manajemen Pendidikan dan Skripsi Karya Ilmiah). Secara rinci kontribusi tersebut divisualisasikan, sebagai berikut.

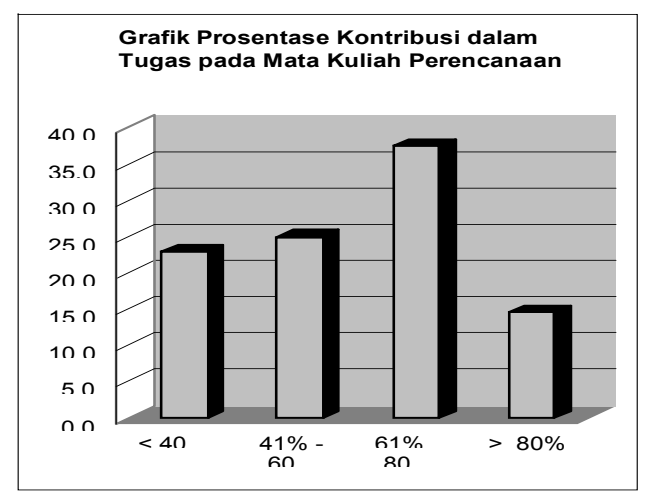

Gambar 3. Grafik persentase kontribusi mata kuliah perencanaan dalam tugas

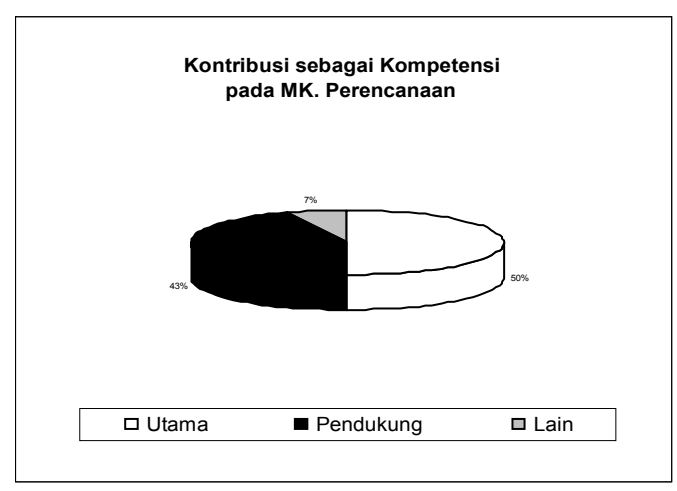

Gambar 4. Kontribusi mata kuliah perencanaan sebagai kompetensinya

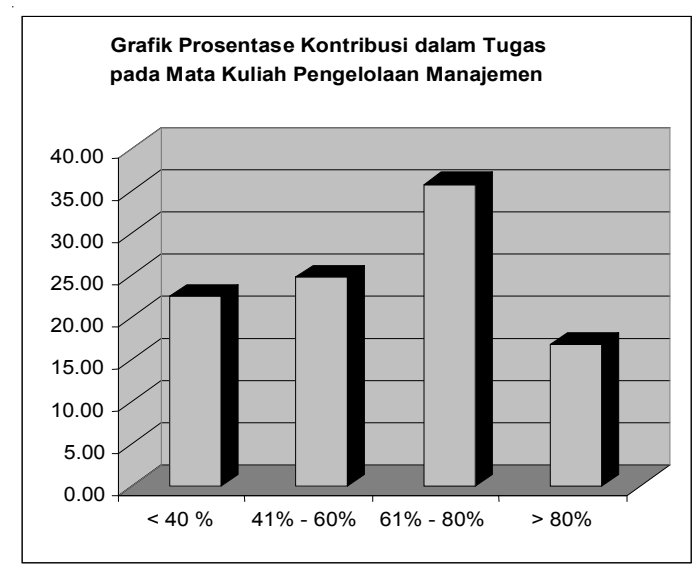

Gambar 5. Grafik persentase kontribusi mata kuliah pengelolaan manajemen dalam tugas

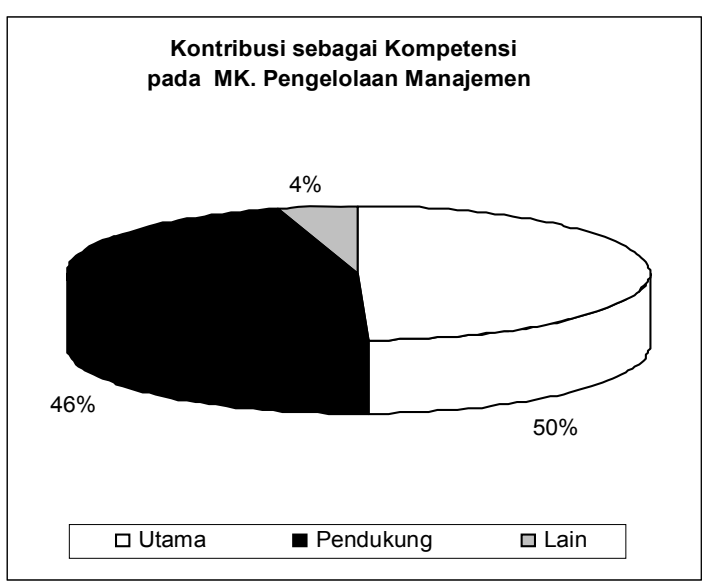

Gambar 6. Kontribusi pada mata kuliah pengelolaan manajemen sebagai kompetensi

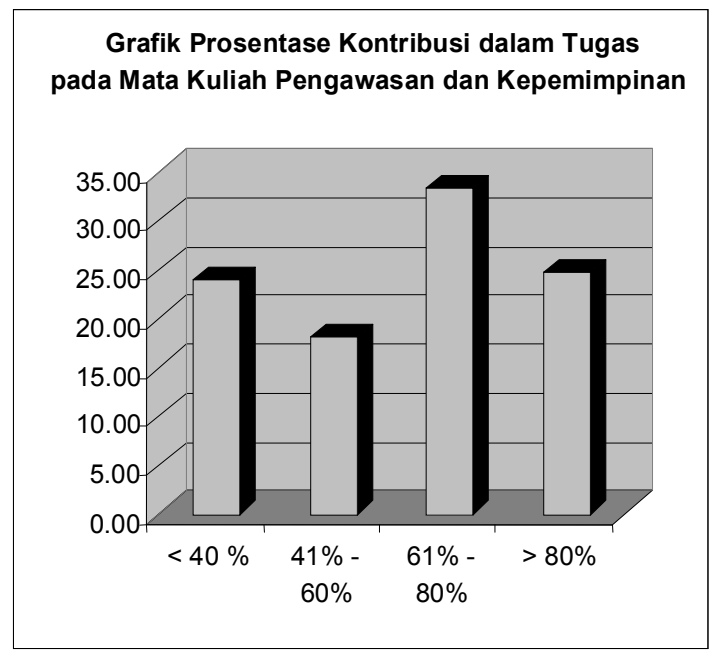

Gambar 7. Grafik persentase kontribusi mata kuliah pengawasan dan kepemimpinan dalam tugas

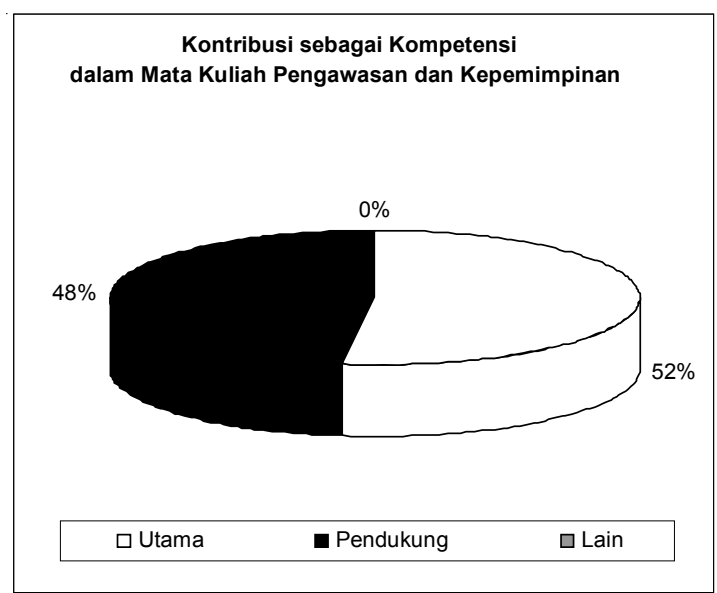

Gambar 8: Kontribusi pada mata kuliah pengawasan dan kepemimpinan sebagai kompetensi 


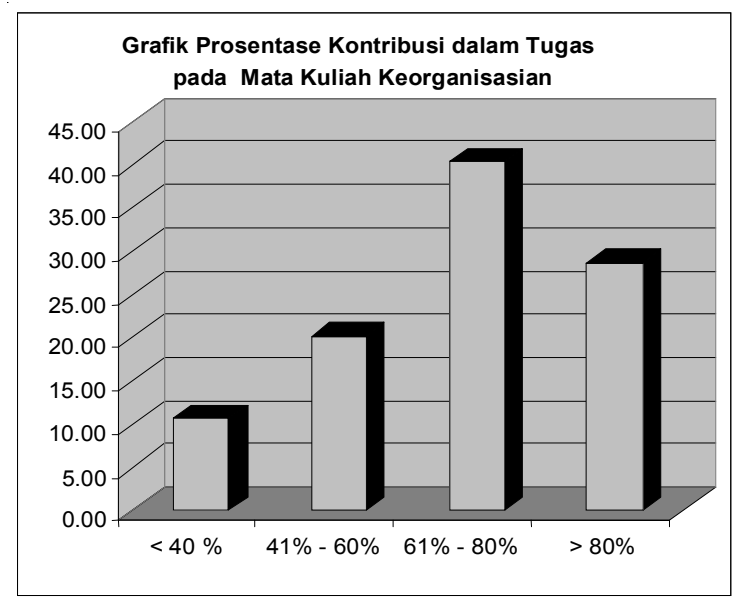

Gambar 9. Grafik Persentase Kontribusi Mata Kuliah Keorganisasian dalam tugas

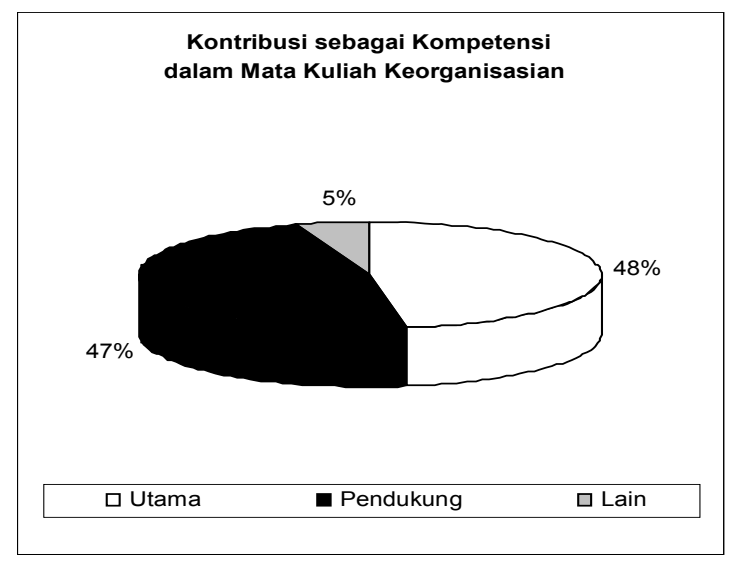

Gambar 10. Kontribusi pada mata kuliah keorganisasian sebagai kompetensi

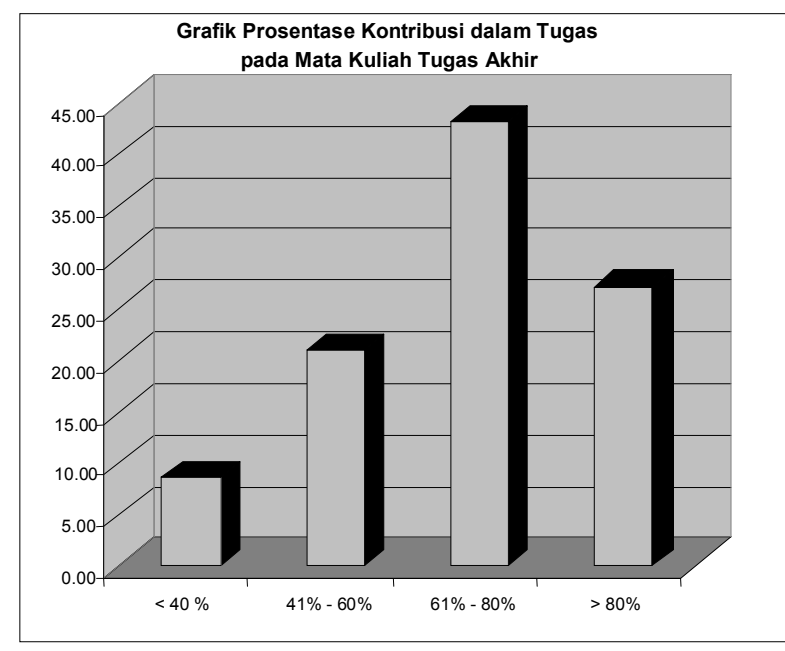

Gambar 11. Grafik persentase kontribusi mata kuliah tugas akhir dalam tugas

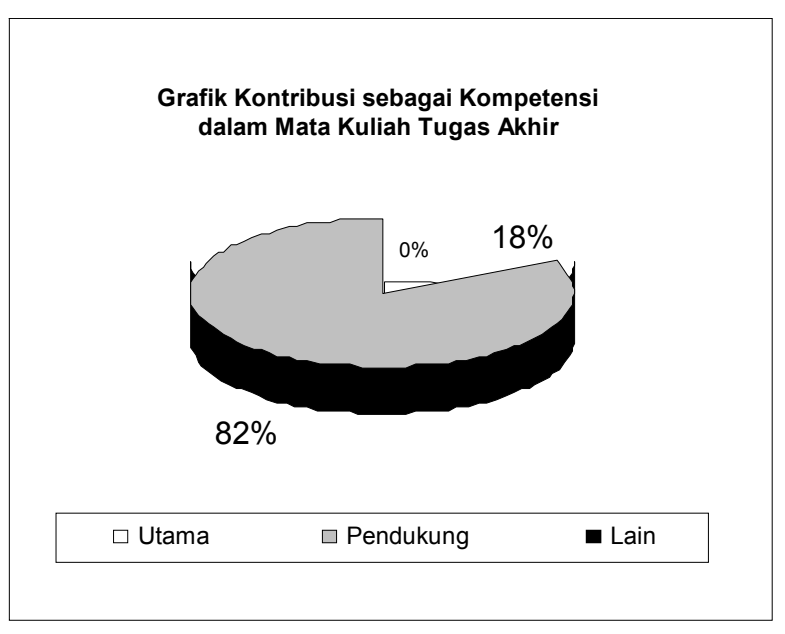

Gambar 12. Kontribusi pada mata kuliah tugas akhir sebagai kompetensi

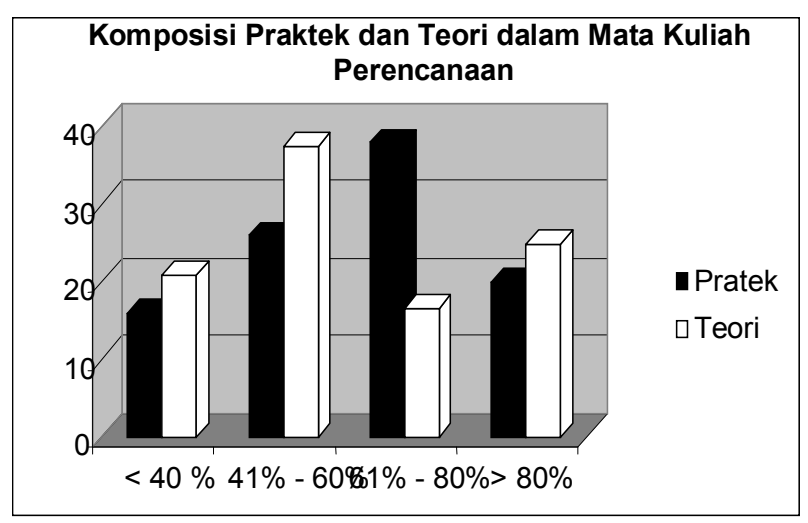

Gambar 13. Grafik komposisi praktek dan teori dalam mata kuliah perencanaan

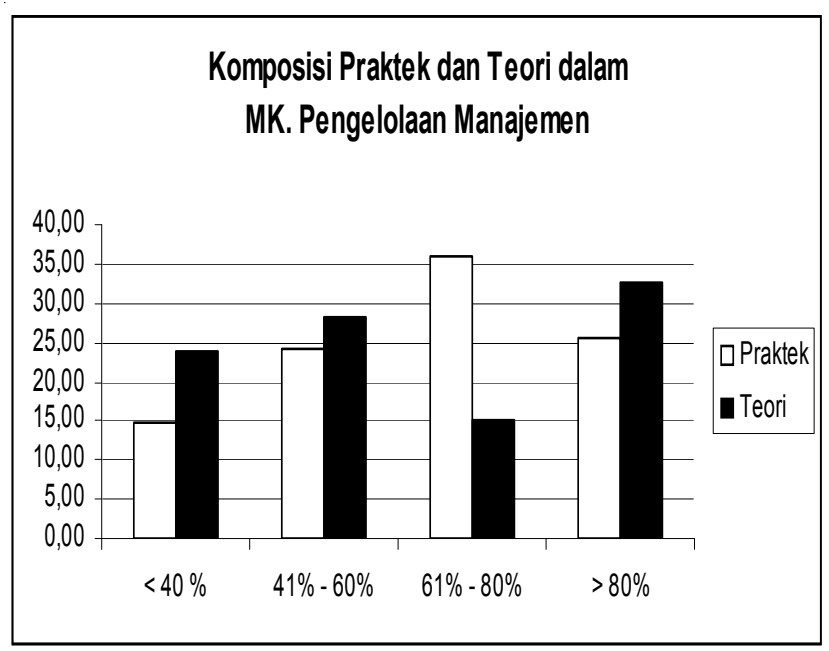

Gambar 14. Grafik komposisi praktek dan teori dalam mata kuliah pengelolaan manajemen 


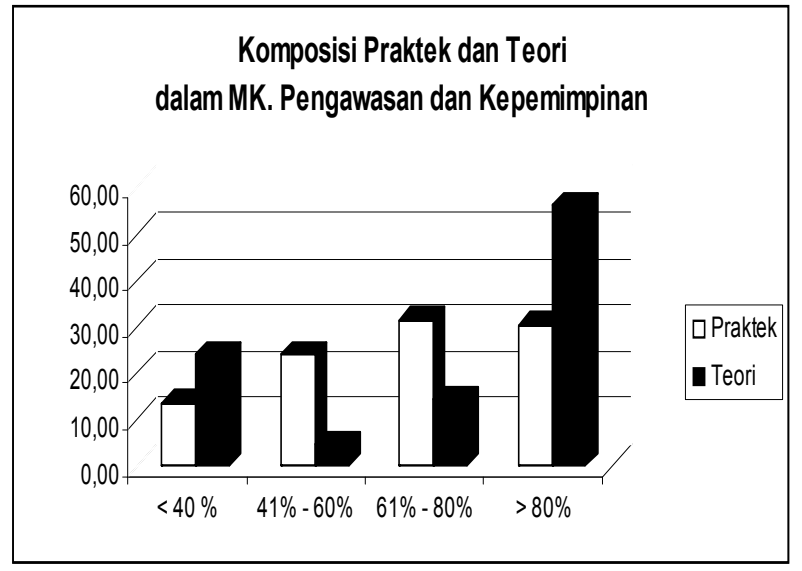

Gambar 15. Grafik komposisi praktek dan teori dalam mata kuliah pengawasan dan kepemimpinan

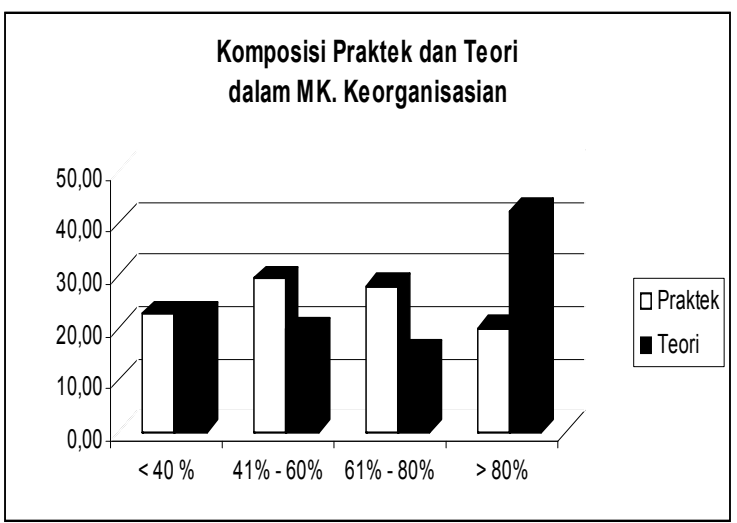

Gambar 16. Grafik komposisi praktek dan teori dalam mata kuliah keorganisasian

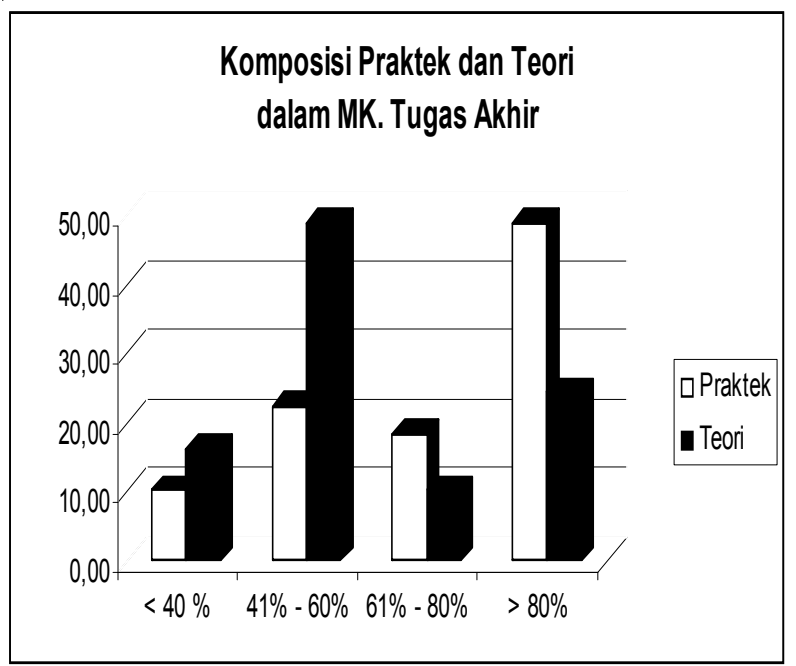

Gambar 17. Grafik komposisi praktek dan teori dalam mata kuliah tugas akhir
Menurut pandangan para alumni mengenai kompetensi dan kualifikasi yang harus dimiliki oleh lulusan Manajemen Pendidikan sebagai pengelola pendidikan dan satuan lembaga lain pada multilevel, lulusan Manajemen Pendidikan harus memiliki kemampuan mengelola pendidikan atau ahli di bidang perencanaan, pengelolaan, dan pengawasan pada level sekolah dan kantor-kantor pendidikan. Selain itu, pengelolaan difokuskan kepada kemampuan mengelola keuangan khususnya pertanggungjawaban sesuai peraturan yang ada. Lulusan MP diharapkan pula menguasai $\mathrm{Hi}$-Tech, mampu berkomunikasi dengan bahasa asing, tanggap, siap, responsif terhadap kondisi yang ada, memahami organisasi, memiliki wawasan kualitas, IMTAQ dan IPTEK, serta mampu menjadi pemimpin masa depan.

Selanjutnya untuk pengembangan jurusan Manajemen Pendidikan ke depan, para alumni secara garis besar menyatakan bahwa perkuliahan sebaiknya lebih banyak diskusi, praktik dan studi lapangan, terutama untuk mata kuliah perencanaan, keuangan, dan sistem informasi manajemen.

Untuk peningkatan perkuliahan perlu peningkatan sarana dan media belajar serta peningkatan sumber daya manusia, misalnya dengan mengadakan seminar-seminar untuk para dosen dan para mahasiswa serta peningkatan disiplin perkuliahan. Dalam mengembangkan silabus, sebaiknya $75 \%$ difokuskan kepada pembentukan tenaga kependidikan yang siap pakai.

Perkenalan jurusan MP ke masyarakat luas dapat dengan melakukan promosi atau mengadakan networking dengan lembaga pendidikan yang bertaraf internasional. Selain itu, dapat pula menyelenggarakan kerjasama dengan seksi pendidikan di kecamatankecamatan untuk melaksanakan perkuliahan dengan kelompok-kelompok belajar di lokasi setempat.

Para alumni menyarankan agar jurusan MP dapat menembus jajaran birokrasi dalam rangka memperjuangkan sertifikasi MP sebagai prasyarat menduduki jabatan Kepala Sekolah. Selain itu, dapat pula membentuk ikatan alumni yang diisi dengan berbagai kegiatan alumni dalam rangka menunjang karir dan pengembangan jurusan MP.

\section{Analisis Hasil Penelitian}

Para stakeholder menyatakan bahwa jurusan Manajemen Pendidikan (MP) adalah lembaga yang menyiapkan sumber daya manusia (SDM) pendidikan yang profesional, memiliki kemampuan dan keterampilan di bidang teknis manajemen, dan jurusan yang menyiapkan pemimpin yang visioner. Jurusan MP juga menyiapkan SDM yang memiliki kemampuan di 
bidang perencanaan, pengelolaan dan pengawasan, serta menghasilkan lulusan yang memiliki kinerja yang memadai. Hal tersebut dinyatakan oleh 53,85 \% responden yang menyatakan setuju dan 43,08\% responden yang menyatakan sangat setuju. Dengan demikian, sebesar 97\% stakeholder menyatakan bahwa jurusan MP menghasilkan lulusan yang memiliki kompetensi di bidang manajemen pendidikan dan jurusan yang menyiapkan pemimpin masa depan.

Ditinjau dari kinerja yang ditunjukkan oleh para lulusan MP, berdasarkan pendapat dari para pemimpin atau atasan langsung, untuk kedisiplinan, $38,46 \%$ menyatakan sangat baik dan $46,15 \%$ baik. Data ini mengindikasikan lebih dari $80 \%$ lulusan MP memiliki tingkat kedisiplinan yang tinggi. Untuk inisiatif kerja lebih dari 85\% menyatakan baik. Sedangkan untuk kreativitas, di atas 85\% lulusan MP memiliki kreativitas kerja baik. Pada aspek kerjasama, menurut penilaian atasan langsung $76 \%$ baik, sedangkan dalam menyusun program, mengelola kegiatan dan keakuratan menyusun laporan hampir 70 persen menyatakan baik.

Untuk pelaksanaan tugas sehari-hari, alumni MP memiliki kemampuan yang baik dalam kemampuan bernegosiasi, memobolisasi, memotivasi, tanggap, kreatif, aktif, dan inovatif.

Berdasarkan data tersebut, secara nyata para stakeholder mengakui bahwa jurusan MP dibutuhkan oleh masyarakat, khususnya dalam hal pengelolaan pada tingkatan institusi makro yaitu kantor-kantor pendidikan yang mengelola pendidikan tingkat pada level nasional, regional, serta pada tingkatan mikro yaitu pada institusi persekolahan.

Mengenai mata kuliah-mata kuliah yang memberikan kontribusi besar dalam pelaksanaan kerja, mata kuliah perencanaan memberikan kontribusi utama sebesar $50 \%$. Ini berarti mata kuliah perencanaan sangat dibutuhkan dalam melaksanakan tugas sehari-hari. Untuk mata kuliah pengelolaan atau manajemen, seperti manajemen ketenagaan, manajemen kesiswaan, kurikulum, keuangan, sarana dan prasarana, manajemen proyek, hubungan sekolah dan masyarakat memberikan kontribusi 50\% mata kuliah yang dapat diaplikasikan dalam melaksanakan tugas sehari-hari. Hal ini menunjukkan bahwa mata kuliahmata kuliah yang diberikan di jurusan sangat dibutuhkan pada saat melaksanakan tugas. Mata kuliah kepengawasan dan kepemimpinan memiliki kontribusi yang cukup tinggi yaitu 52\% dalam melaksanakan tugas, hal ini mengindikasikan bahwa mata kuliah kepengawasan dan kepemimpinan sangat menunjang dalam melaksanakan tugas sehari-hari, terutama bagi para pengawas dan pengelola dan pemimpin pendidikan. Mata kuliah kelompok keorganisasian memiliki kontribusi $48 \%$ sebagai kontribusi utama yang menunjukkan bahwa mata kuliah ini juga sangat menunjang dalam implementasi tugas. Selanjutnya untuk tugas akhir yaitu skripsi dan karya ilmiah memberikan kontribusi pendukung sebesar $82 \%$, hal ini berarti pengalaman menulis dan meneliti tentang kajian manajemen pendidikan dibutuhkan dalam melaksanakan tugas dan pengembangan karir.

Pada mata kuliah perencanaan, di atas 58\% responden menyatakan membutuhkan praktek lebih banyak dari pada teori. Sedangkan untuk mata kuliah kelompok pengelolaan atau manajemen, 61\% responden menyatakan kebutuhan untuk praktek. Untuk mata kuliah pengawasan dan kepemimpinan $62 \%$ responden menyatakan kebutuhan untuk praktek lebih banyak dibandingkan teori, begitu pula untuk mata kuliah tugas akhir. Sedangkan untuk mata kuliah keorganisasian hanya $52 \%$ responden yang menyatakan teori lebih diperlukan. Berdasarkan data tersebut menunjukkan bahwa responden menginginkan atau membutuhkan kuliah yang bersifat aplikasi lebih banyak dibandingkan kuliah yang bersifat teoretik.

Ditinjau dari aspek kontribusi makadapat diurutkan, mata kuliah pengawasan dan kepemimpinan memiliki kontribusi tertinggi diikuti dengan mata kuliah perencanaan, pengelolaan, dan keorganisasian. Sedangkan untuk kebutuhan perkuliahan yang aplikatif, yaitu mata kuliah pengelolaan sedangkan mata kuliah yang cenderung teoritik untuk mata kuliah keorganisasian.

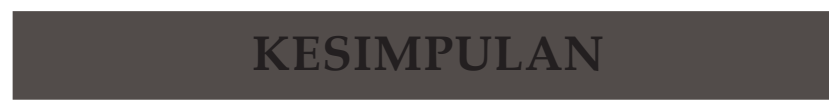

Menurut persepsi dan atau penilaian stakeholder (pimpinan pada level top, middle, dan operational), jurusan Manajemen Pendidikan sangat dibutuhkan oleh masyarakat, khususnya dalam kompetensi pengelolaan pendidikan yang meliputi perencanaan, pengelolaan, pengawasan, dan penilaian.

Stakeholder juga menyatakan para lulusan jurusan Manajemen Pendidikan memiliki kinerja yang tinggi dilihat dari aspek kedisiplinan, inisiatif, kreativitas, kerjasama, kemampuan menyusun program, serta akurat dalam menyusun laporan.

Berdasarkan hasil telusuran alumni disimpulkan bahwa mata kuliah yang diberikan di jurusan Manajemen Pendidikan memiliki relevansi yang tinggi dengan dunia kerja serta memberikan kontribusi utama dalam melaksanakan tugas sehari-hari. Selain itu, rata- 
rata di atas 50\% bahwa mata kuliah yang diberikan di jurusan membutuhkan praktek atau implementasi lapangan.

Para stakeholder mengharapkan lulusan Manajemen Pendidikan memiliki kemampuan yang kompetitif dalam melaksanakan unjuk kerja. Selain itu, jurusan Manajemen Pendidikan dapat melayani dan mengakomodasi kebutuhan masyarakat akan kompetensi Manajemen Pendidikan, seperti layanan sertifikasi kepengawasan, ke kepala sekolahan, dan ketatausahaan sekolah yang berbasis teknologi informasi.

Disarankan pula perkuliahan yang diberikan berbasis teknologi informasi sesuai tuntutan kebutuhan masyarakat pada era global dan cepat berubah.

\section{Saran}

Berdasarkan hasil kajian dan kesimpulan, maka jurusan Manajemen Pendidikan sangat dibutuhkan oleh stakeholder, sangat perlu membenahi kurikulum yang diawali dengan perumusan baru visi dan misi, dan merestrukturasi kurikulum untuk disesuaikan dengan kebutuhan stakeholder.

Menyiapkan kondisi pembelajaran dengan mempelajari kajian Manajemen Pendidikan yang diselaraskan dengan percepatan perkembangan pengetahuan dan teknologi serta responsif terhadap kebijakan dan kebutuhan masyarakat, seperti mengadakan seminar dan lokakarya, serta mendayagunakan tenaga ahli dan praktisi untuk memberikan kuliah kepada mahasiswa.

Mahasiswa juga perlu melakukan studi lapangan yang intensif dalam rangka mengaplikasikan teori akademik, baik dalam bentuk tugas perkuliahan serta tugas akhir untuk memperoleh gelar sarjana Manajemen Pendidikan

\section{DAFTAR PUSTAKA}

Goetch, L., \& Davis, S.B. (1997). Introduction to total quality. New Jersey: Prentice Hall.

Hom, W.C. Applying customer satisfaction theory to community college planning of student services. Diakses pada September 2002, dari http:// w w w.ijourna $1 . u s /$ is sue_02/ ij_issue02_WillardHom_01.htm)
Hrandesky, J. (1995). Total quality manajement handbook. USA : Mc. Graw-Hill.

Joel, E.R. (1995). Total quality management. Singapore: Mubarok and Brothers.

Kepmendiknas RI No. 045/U/2002. Kurikulum inti pendidikan tinggi. Diakses pada tanggal 27 Agustus 2009, dari http://www.dikti.go.id/ archive2007/kepmendiknas_no_045u2002.htm

Kepmendiknas RI No. 232/U/2000. Pedoman penyusunan kurikulum pendidikan tinggi dan penilaian hasil belajar mahasiswa. Diakses pada tanggal 27 Agustus 2009, dari http:// www.dikti.go.id/Archive2007/-kepmen2322000.txt

Mulyasa. (2003). Kurikulum berbasis kompetensi. Bandung: Remaja Rosdakarya.

Nasution, M.N. (2001). Manajemen mutu terpadu. Jakarta : Ghalia Indonesia.

Sallis. (1993). Total quality managenent in education. London : Koogan.

Semiawan, C. (1992). Kurikulum berdiferensiasi. Jakarta: Grasindo.

Stamatis, D.H. (1997). Total quality service. New Delhi: Vanity Book International.

Suriasumantri. (2000). Perekayasaan kurikulum. Bandung: Angkasa.

Tjiptono, F. (2000). Prinsip-prinsip total quality management. Yogyakarta: Andi.

Wasty, H. (1996). Pembinaan kurikulum. Surabaya: Usaha Nasional.

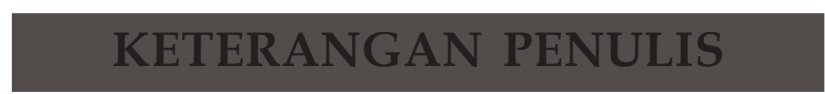

Rugaiyah, saat ini aktif sebagai dosen jurursan Manajemen Pendidikan Fakultas Ilmu Pendidikan Universitas Negeri Jakarta. 